\title{
The Credit Channel of Capital Tax Policy
}

\author{
Holger Strulik ${ }^{*}$ \\ University of Hannover
}

Revised Version, April 2008

A neoclassical growth model is augmented by a corporate sector, financial intermediation, and a set of tax rates. In this setting, capital structure is determined by the interplay between a tax advantage of debt finance and costly state verification entailed by asymmetric information. Effects of capital tax reforms are investigated with a special focus on this micro-founded credit channel of tax policy. The theoretical part of the article establishes a new, institution-based view on the motivation of debt finance in general equilibrium and derives financial and real effects of private and corporate income tax policies. Using a calibration with U.S. data, the applied part demonstrates that tax cuts cause significant adjustments of capital structure. Nevertheless, it turns out that the credit channel generates relatively small effects of tax reforms on consumption, investment, and growth.

Keywords: Tax Reform, Corporate Finance, Agency Costs, Economic Growth. JEL Classification: H30, E44, E62, O16.

\footnotetext{
*I would like to thank Charles Carlstrom, Karl Dietrich, Michael Funke, Christian Groth, Ines Lindner, Christian Schumacher, and Nikolaus Siegfried, participants at seminars in Hannover and Copenhagen, and the World Congress of the Econometric Society 2005, and an anonymous referee for useful comments. Correspondence: University of Hannover, Wirtschaftswissenschaftliche Fakultät, Königsworther Platz 1, 30167 Hannover, Germany; email: strulik@vwl.uni-hannover.de.
} 


\section{INTRODUCTION}

The question to what extent capital tax reforms may affect long-run economic performance has been on the economics research agenda for a long time. Most macro-economic empirical studies and calibration exercises suggest significant effects of taxation on investment and thereby on the level of the growth path but only little effects on the long-run growth rate itself. ${ }^{1}$ Usually, the employed theoretical explanation is based on the neoclassical cost-of-capital effect. While the applied microeconomic literature finds some evidence for a cost-of-capital effect, it also emphasizes a second important effect of capital taxation through the adjustment of capital structure. Taxation of private and corporate income affects financial decisions of firms and through this credit channel investment and the real economy. ${ }^{2}$ The possibility that capital taxation has an impact on longrun economic performance through the credit channel is usually neglected in the economic growth literature. The present article investigates to what extent its consideration modifies previous results.

The introduction of a credit channel of capital taxation into a neoclassical growth model is built upon the literature on credit market frictions in real business cycle research. Bernanke and Gertler (1989, 1999), Fuerst (1995), and Carlstrom and Fuerst (1997, 2001) have investigated Townsend's (1979) theory of costly state verification within a general equilibrium framework. There, entrepreneurs can finance their projects with equity and debt. Because of asymmetric information about productivity (an idiosyncratic stochastic variable) and the involved agency problem, they contract with lenders in form of an optimal debt contract. According to this contract, costs of debt will be the higher the lower an entrepreneur's net worth. Because net worth behaves pro-cyclically, agency costs propagate the impact of shocks on the economy and generate a realistic pattern of the business cycle. The mechanism has therefore been characterized as financial accelerator (Bernanke and Gertler, 1996).

Using this mechanism, the present article pursues a different object of investigation, the longrun macroeconomic consequences of tax reforms. Because the focus is on long-run effects, macroeconomic shocks (other than tax reforms) are neglected. After aggregation all idiosyncratic risk is eliminated and the aggregate model is in fact deterministic. It will be first investigated analytically.

\footnotetext{
${ }^{1}$ See, for example, Lucas (1990), Stokey and Rebelo (1995), Mendoza et al. (1997).

${ }^{2}$ See, for example, for example Cummins et et. al. (1996) and Chirinko et al. (1999) for the cost-of-capital effect, Graham (1999) and Gordon and Lee (2001) for evidence on the impact of taxation on capital structure and Fazzari et al. (1988), Hubbard (1998), Gilchrist and Himmelberg (1998) for evidence of the impact of credit constraints on investment.
} 
Several interesting results on firm finance and investment, comparative statics of tax reforms, and adjustment dynamics after capital tax cuts will be derived. In the second part of the article the model is calibrated with U.S. data and consequences of tax reforms are assessed quantitatively.

The introduction of a detailed tax system allows a different view on the motivation of debt finance. The existing general equilibrium theory with agency costs employs a behavioral explanation for debt demand. There, the inherent disadvantage of debt finance is not counterbalanced by a similar inherent advantage of debt finance, implying that without further assumption all firms would be completely equity-financed eventually. To generate debt demand it is therefore assumed that firms are owned and managed by a certain fraction of the total population, called entrepreneurs. Entrepreneurs are then assumed to have either a shorter life or to discount the future more heavily than other households.

In contrast to this literature, the present article investigates an institutional explanation for capital structure. People are assumed to be identical with respect to preferences and life length. Firms, however, are modelled as corporations whose shares are owned by households. In this framework we introduce a government that levies taxes on corporate and private income. The interplay between corporate and private taxes creates a tax advantage of debt finance. Together with the counterbalancing disadvantage of debt finance resulting from asymmetric information and costly monitoring, an interior solution for debt demand is established. ${ }^{3}$

The present work also refers to a series of earlier articles which have investigated the impact of capital taxation on corporate finance and investment in a dynamic equilibrium context. These models either obtain a corner solution for capital structure (Turnovsky, 1982, 1990, Sinn, 1987) or an interior solution is generated through the assumption of an agency costs function (Osterberg, 1989, Strulik, 2003). Models of the latter type share with the present article that calibrations with actual data yield good approximations of the observed correlations between taxation, capital structure and investment. Agency costs, however, are imposed rather than generated through interaction between lenders and borrowers so that these models cannot satisfactorily explain why fiscal policy has affected financial decisions of firms and the real economy. The present article resolves this problem by explaining capital structure through an optimal debt contract whose terms will depend on the design of the fiscal system. In the words of Bernanke and Gertler (1996)

\footnotetext{
${ }^{3}$ To my knowledge the interplay of costly state verification and corporate finance has not yet been investigated in dynamic general equilibrium. Gertler and Hubbard (1993) investigate a partial equilibrium model on the equity cushion and dividend policy.
} 
the analysis takes place inside the black box.

The article is organized as follows. The next section augments the neoclasssical growth model by a corporate sector, a state verification problem, and a set of fiscal policy parameters. Section 3 derives the central correlations between the macro-economy (summarized by the aggregate capital stock and the resulting interest rate) and the financial decision of firms (described by critical default values and costs of debt). Stability of equilibrium, comparative statics, and adjustment dynamics after tax reforms are derived in Section 4. Section 5 calibrates the model with U.S. data and investigates the quantitative impact of tax reforms. It compares the solution with the one obtained for the standard model without corporate sector and debt finance. Section 6 extends the analysis to human capital driven growth and re-assesses the growth effects of tax-reforms within a finance augmented model of the Lucas (1990)-type. A final section concludes.

\section{MODEL}

2.1. Firms. Consider an economy populated by a continuum of competitive firms with measure one. Time is discrete. In period $t$ a firm $i \in[0,1]$ operates a c.r.s. technology to produce output

$$
Y_{t}(i)=\omega_{t}(i) F\left(K_{t}(i), A_{t} L_{t}(i)\right)
$$

The inputs are capital, $K_{t}(i)$, and labor $L_{t}(i)$. The deterministic function $F$ exhibits positive and decreasing marginal returns and fulfils the Inada conditions. $A_{t}$ denotes the current level of technology, i.e. aggregate productivity faced by all firms. Production is also subject to an idiosyncratic productivity shock $\omega_{t}(i)$ with mean one, distribution function $\phi$, and density function $\Phi .^{4}$

Each unit of labor receives a wage $w_{t}$ and each unit of capital receives an interest rate $r_{t}$ so that total factor costs are given by

$$
X_{t}(i)=w_{t} L_{t}(i)+r K_{t}(i)
$$

Capital consists of equity capital $K_{t}^{E}(i)$ and capital rented from households, $K_{t}^{H}(i)$. It depreciates at rate $\delta$. The wage bill and the costs of rented capital have to be payed upfront before production and sales commence and before the idiosyncratic productivity shock is observed. These costs are financed by one-period debt borrowed from households through a risk-neutral financial intermediary called bank. The sole role of banks is to eliminate idiosyncratic uncertainty by the law of large

\footnotetext{
${ }^{4}$ The notation is summarized in Table 1.
} 
numbers and to guarantee a sure return to the suppliers of labor and capital.

The credit market is built upon Townsend's (1979) theory of costly state verification. External parties can observe the shock $\omega_{t}(i)$ only by paying a monitoring cost proportional to the project size, $\mu X_{t}(i)$. In case of default the bank seizes all output. Otherwise the loan is repaid and the firm keeps excess output. The possibility of bankruptcy implies that output is sold at a higher price than production costs in order to cover the expected bankruptcy costs. In other words, factor prices are below their marginal products. Output prices are normalized to one. Let $s_{t}>1$ denote the markup so that expected output sells at $F\left(K_{t}(i), A_{t} L_{t}(i)\right)=F_{K t} K_{t}(i)+F_{L t} L_{t}(i)=s_{t}\left(r_{t} K_{t}(i)+w_{t} L_{t}(i)\right)$ and factor prices are given by

$$
r_{t}=\frac{F_{K t}}{s_{t}}, \quad w_{t}=\frac{F_{L t}}{s_{t}} .
$$

Note that factor prices and the markup are not decision variables of the single firm, because firms are assumed to operate on competitive markets. The markup is obtained in equilibrium such that sales cover factor costs, return on equity, and the costs of debt finance. It converges to 1 when the debt ratio converges to zero, i.e. when the model converges towards the standard neoclassical growth model. The higher the debt ratio and thus the probability of bankruptcy for any given shock $\omega_{t}(i)$, the higher the agency costs of debt and thus $s_{t}$. This way, the markup indicates the costs of leverage in the economy.

Contracts between firms and banks specify the critical shock value $\bar{\omega}_{t}(i)$ that triggers bankruptcy. Since net worth, $N_{t}(i)=\left(1+r_{t}-\delta\right) K_{t}^{E}(i)$, is given at the beginning of period, the critical $\bar{\omega}_{t}(i)$ indirectly determines the total amount borrowed, $X_{t}(i)-N_{t}(i)$, and thus total factor input and production of period $t$. In order to see this clearly let $f\left(\bar{\omega}_{t}(i)\right)$ define the share of output that firm $i$ expects to receive.

$$
f\left(\bar{\omega}_{t}(i)\right)=\int_{\bar{\omega}_{t}(i)}^{\infty}\left(\omega_{t}(i)-\bar{\omega}_{t}(i)\right) \phi\left(\omega_{t}(i)\right) \mathrm{d} \omega_{t}(i)=\int_{\bar{\omega}_{t}(i)}^{\infty} \omega_{t}(i) \phi\left(\omega_{t}(i)\right) \mathrm{d} \omega_{t}(i)-\left[1-\Phi\left(\bar{\omega}_{t}(i)\right)\right] \bar{\omega}_{t}(i)
$$

and hence

$$
f^{\prime}\left(\bar{\omega}_{t}(i)=\Phi\left(\bar{\omega}_{t}(i)-1<0, \quad f^{\prime \prime}\left(\bar{\omega}_{t}(i)=\phi\left(\bar{\omega}_{t}(i)>0\right.\right.\right.\right.
$$

A bank expects to receive the output share

$$
g\left(\bar{\omega}_{t}(i)\right)=\int_{0}^{\bar{\omega}_{t}(i)} \phi\left(\omega_{t}(i)\right) \omega_{t}(i) \mathrm{d} \omega_{t}(i)-\mu \Phi\left(\bar{\omega}_{t}(i)\right)+\left[1-\Phi\left(\bar{\omega}_{t}(i)\right)\right] \bar{\omega}_{t}(i) .
$$

where the first term on the right hand side is the expected return in case of default, the second term 
is expected monitoring costs, and the last term is the expected share of output from a surviving firm. Subtract the shares of firm and bank from one to obtain the positive deadweight loss (i.e. the agency costs) of debt finance:

$$
1-f\left(\bar{\omega}_{t}(i)\right)-g\left(\bar{\omega}_{t}(i)\right)=\mu \Phi\left(\bar{\omega}_{t}(i)\right) .
$$

The debt contract specifies a critical value for default, $\bar{\omega}_{t}(i)$, such that a firm maximizes expected returns, $f\left(\bar{\omega}_{t}(i)\right) s_{t} X_{t}(i)$, and a bank on average receives its loan back, $s_{t} g\left(\bar{\omega}_{t}(i) X_{t}(i)=X_{t}(i)-\right.$ $N_{t}(i)$. Insert the latter constraint into expected returns to obtain

$$
f\left(\omega_{t}(i)\right) \cdot s_{t} X_{t}(i)=\chi_{t}(i) \cdot N_{t}(i), \quad \text { where } \quad \chi_{t}(i) \equiv \frac{s_{t} f\left(\bar{\omega}_{t}(i)\right)}{1-s_{t} g\left(\bar{\omega}_{t}(i)\right)}
$$

defines the internal rate of return on equity. Note that in a world without debt finance (the standard neoclassical growth model) we would have that $s_{t}=f=1$ and $g=0$. Thus $\chi_{t}=1$ implying that the firm gets "only" the usual return on capital, $N_{t}(i)=\left(1+r_{t}-\delta\right) K_{t}^{E}(i)$. With debt finance the return on equity has to be higher, $\chi>1$ since firms have to make up for the costs of possible bankruptcy. This way $\chi_{t}$ operates as another indicator of leverage.

From the first order condition we obtain an equation that implicitly determines the critical value of default.

$$
s_{t}-\left(1-\mu \Phi\left(\bar{\omega}_{t}(i)\right)+\frac{f\left(\bar{\omega}_{t}(i)\right)}{f^{\prime}\left(\bar{\omega}_{t}(i)\right)} \mu \phi\left(\bar{\omega}_{t}(i)\right)\right)^{-1}=0
$$

Because production exhibits constant returns to scale, a firm's critical value of default is independent from the size of the project. As shown in (9) it depends only on the markup and is therefore independent from idiosyncratic risk. This result reflects the fact that firms are ex ante identical and receive the same debt contract. Consequently, the firm index will be dropped.

For future use we recalculate the risk premium (or lending rate) implied by the contract. A firm borrowing $\left(X_{t}-N_{t}\right)$ commits to repay $\left(1+r_{t}^{L}\right)\left(X_{t}-N_{t}\right)$ and defaults if $\omega_{t} X_{t}<\left(1+r_{t}^{L}\right)\left(X_{t}-N_{t}\right)=$ $\bar{\omega}_{t} X_{t}$. This yields the risk premium $r_{t}^{L}=\bar{\omega}_{t} /\left[s_{t} g\left(\bar{\omega}_{t}\right)\right]-1$. Following the literature we focus on the interesting case where bankruptcy risk and mark-up are positively correlated. This requires the following assumption.

Assumption 1. The hazard rate, $\phi(\bar{\omega}) /[1-\Phi(\bar{\omega})]$, is increasing in $\bar{\omega}$.

So far the analysis coincides with Carlstrom and Fuerst (2001). It will now deviate. Instead of investigating a special class of households, the entrepreneurs, we consider a homogenous population. All households share the same preferences and an infinite life length. They are shareholders of 
firms which are modelled as corporations. In order to keep the analysis tractable we assume that retained earnings are always the preferred source of equity accumulation. ${ }^{5}$

Firms solve an intertemporal problem with respect to equity accumulation and dividend payouts (i.e. the maximization of firm value). Let $D_{t}$ denote gross dividends payed in period $t, \tau_{p}$ the tax rate on private interest income, $\tau_{c}$ the tax rate on capital gains, and let $\theta$ be a factor that converts gross dividends into net dividends. Because firms maximize firm value in favor of households, net dividends and capital gains are discounted by the rate relevant for households. This is the rate of return on riskless bonds $\left(r_{t}^{B}\right.$ in period $\left.t\right)$ net of private income taxes. A firm's expected market value in period $t$ is then given by

$$
V_{t}=E_{t} \sum_{j=t}^{\infty} \prod_{h=t}^{j}\left(\frac{1}{1+\left(1-\tau_{p}\right) r_{h}^{B}}\right)^{h-t}\left[\theta D_{j}-\tau_{c}\left(V_{j+1}-V_{j}\right)\right] .
$$

Calculating the difference between firm value in period $t$ and period $t+1$ we arrive at the no-arbitrage condition for investing in shares and bonds.

$$
\left(1-\tau_{c}\right)\left[V_{t+1}-V_{t}\right]+\theta D_{t}=\left(1-\tau_{p}\right) r_{t}^{B} V_{t}
$$

Re-inserting (10) into $V_{t}$ we obtain the following expression for the expected firm value.

$$
V_{t}=E_{t} \sum_{j=t}^{\infty} \prod_{h=t}^{j}\left[1+\left(1-\tau_{p}\right) r_{h}^{B}\right]^{-(h-t)} \cdot \frac{\theta D_{j}}{1-\tau_{c}} .
$$

Dividends are defined by profits $P_{t}$ minus investment $I_{t}$ and taxes on retained earnings, $T_{t}^{r}$, i.e. $D_{t} \equiv P_{t}-I_{t}-T_{t}^{r}$. Accounting profits are given by net return on equity times equity utilized, $P_{t}=\left[\chi_{t} \cdot\left(1+r_{t}-\delta\right)-1\right] K_{t}^{E}$. The modelling of tax depreciation follows Sinn (1987) by assuming that a proportion $z$ of net investment $I_{t}$ can be deducted from profits immediately. The remainder of gross investment is tax-deductible over time at the rate of economic depreciation. Let $T_{t}^{r}$ denote taxes on retained profits levied at rate $\tau_{r}$ so that $T_{t}^{r}=\tau_{r}\left(P_{t}-D_{t}-z I_{t}\right)$. Insert this and accounting profits into the definition of dividends to obtain

$$
\begin{aligned}
\left(1-\tau_{r} z\right) I_{t} & =\left(1-\tau_{r}\right)\left\{\left[\chi_{t} \cdot\left(1+r_{t}-\delta\right)-1\right] K_{t}^{E}-D_{t}\right\} \Rightarrow \\
K_{t+1}^{E} & =\frac{1-\tau_{r}}{1-\tau_{r} z}\left\{\left[\chi_{t} \cdot\left(1+r_{t}-\delta\right)-1\right] K_{t}^{E}-D_{t}\right\}+K_{t}^{E} .
\end{aligned}
$$

\footnotetext{
$\overline{{ }^{5} \operatorname{Sinn}(1987, \text { Ch}}$. 4.2) argues that this assumption should always be fulfilled under the U.S. tax system. Empirical evidence, however, is somewhat less conclusive, see Auerbach (2002).
} 
A lower corporate tax rate $\tau_{r}$ or a higher tax depreciation $z$ increases ceteris paribus the accumulation of equity capital.

A firm uses the control variables of dividends $D_{t}$ and equity accumulation $K_{t+1}^{E}$ to maximize shareholder value (11) subject to the equation of motion (12) taking tax parameters, interest rates, and $\chi_{t}$ as implied by each period's debt contract as given. ${ }^{6}$ This leads to the following first order conditions.

$$
\begin{aligned}
& \frac{\theta}{1-\tau_{c}}-q_{t} \frac{1-\tau_{r}}{1-\tau_{r} z}=0 \\
& q_{t}\left\{\frac{1-\tau_{r}}{1-\tau_{r} z}\left[\chi_{t} \cdot\left(1+r_{t}-\delta\right)-1\right]+1\right\}=q_{t-1}\left[1+\left(r_{t}-\delta\right)\left(1-\tau_{p}\right) /\left(1-\tau_{c}\right)\right] .
\end{aligned}
$$

Here $q_{t}$ is the Lagrange multiplier associated with period $t$ 's budget constraint, i.e. it is the shadow price of equity. Condition (13a) shows that the shadow price of equity is different from one and depends on the structure of the tax system. Because tax rates are given parametrically and are not expected to change, $q_{t}$ is actually invariant over time. This time invariance implies that $q_{t}$ and $q_{t+1}$ cancel out in (13b). From condition (13b) we then conclude that firms react on an unexpected, permanent change of tax rates by adjusting either the structure of production (reflected on the macro-level by a changing $r_{t}$ ), or the structure of finance (and thereby changing $\chi_{t}$ ), or both. The interplay of these adjustments is investigated in Section 3 and 4.

2.2. Households. The economy is populated by a continuum of households. Households are the ultimate suppliers of debt and equity. In a period $t$ they rent capital $K_{t}^{H}$ to firms at rate $r_{t}$ and hold stocks $V_{t}$, which provide capital gains $\left(V_{t+1}-V_{t}\right)$. In addition, they receive capital income from holding bonds $\left(B_{t}\right)$ at an interest rate $r_{t}^{B}$ and from dividends. With the exception of capital gains all capital income is taxed at a unique rate $\tau_{p}$. Depreciation is tax deductible. Capital gains are taxed at an effective rate $\tau_{c}$. Households supply $L_{t}$ units of labor for which they receive wages $w_{t}$ taxed at rate $\tau_{w}$. In order to develop the main mechanics of the model analytically, labor supply is assumed to be fixed at this stage of investigation. Leisure and human capital formation are introduced at later stages. Finally, households receive lump sum transfers $T_{t}$ from the government. In summary, their budget constraint is given by

$B_{t+1}+K_{t+1}^{H}=\left(1-\tau_{w}\right) w_{t} L_{t}+\left(1-\tau_{p}\right) r_{t}^{B} B_{t}+\left(1-\tau_{p}\right)\left(r_{t}-\delta\right) K_{t}^{H}+\theta D_{t}+T_{t}+B_{t}+K_{t}^{H}-\tau_{c}\left(V_{t+1}-V_{t}\right)-C_{t}$.

${ }^{6}$ Of course, it would be desirable to have also long-term debt contracts, i.e. debt as another state variable. This would, however, tremendously complicate the analysis and is - as in the literature on which the present article is based - neglected. 
TABle 1: VARIABles AND PARAMETERS

\begin{tabular}{|c|c|c|c|}
\hline \multicolumn{4}{|c|}{ Variables } \\
\hline$A$ & technology level (grows at rate $\gamma$ ) & $b$ & debt ratio, $b \equiv 1-f(\bar{\omega})$ \\
\hline$B$ & bond holdings of households & $c$ & consumption in efficiency units, $c \equiv C /(A L)$ \\
\hline$C$ & consumption & $k$ & capital in efficiency units, $k \equiv K /(A L)$ \\
\hline$D$ & dividends & $q$ & shadow price of capital \\
\hline$I$ & net investment & $r$ & rental rate for capital \\
\hline$K$ & capital stock & $r^{B}$ & interest rate on bonds $\left(r^{B}=r-\delta\right)$ \\
\hline$K^{E}$ & equity capital & $r^{L}$ & risk premium \\
\hline$K^{H}$ & capital rented from households & $s$ & markup factor \\
\hline$L$ & employment & $w$ & wage rate \\
\hline$N$ & net worth & $\chi$ & internal rate of return on equity \\
\hline$P$ & profits & & idiosyncratic productivity shock \\
\hline$V$ & firm value & $\bar{\omega}$ & critical default value \\
\hline$W$ & total financial wealth of households & & index of time \\
\hline$X$ & project size & $j, h$ & auxiliary index of time \\
\hline$Y$ & output & & index of firm \\
\hline \multicolumn{4}{|c|}{ Parameters: technologies and preferences } \\
\hline$\alpha$ & production elasticity of capital & $\eta$ & determines labor supply elasticity \\
\hline$\beta$ & time discount factor & $\mu$ & bankruptcy costs, fraction of project size \\
\hline $\begin{array}{l}\gamma \\
\delta\end{array}$ & $\begin{array}{l}\text { growth rate of technological progress } \\
\text { depreciation rate }\end{array}$ & $\sigma$ & elasticity of marginal utility (of $C$ ) \\
\hline \multicolumn{4}{|c|}{ Parameters: policy } \\
\hline$g_{s}$ & government share of GDP & $T$ & transfers to households \\
\hline$\tau_{c}$ & tax rate on capital gains & $\tau_{p}$ & tax rate on private capital income \\
\hline$\tau_{r}$ & tax rate on corporate profits & $\tau_{w}$ & tax rate on wage income \\
\hline$\theta$ & conversion factor, gross to net dividends & $z$ & immediate tax depreciation rate \\
\hline
\end{tabular}

The following symbols are used for functions. $F$ : production, $f$ : equity's share of output, $g$ debt's share of output, $\Phi$ : cdf of productivity shock, $\phi$ : pdf of productivity shock. Thus, $\Phi(\bar{\omega})$ identifies the bankruptcy rate. All variables are generally indexed by time. The extension towards endogenous growth requires some additional notation which is explained in the text.

No-arbitrage requires that $r_{t}^{B}=\left(r_{t}-\delta\right)$ in equilibrium. Let $W_{t}$ denote total financial wealth in period $t, W_{t}=B_{t}+K_{t}^{H}+V_{t}$. Using (10) the budget constraint simplifies to

$$
W_{t+1}=\left(1-\tau_{w}\right) w_{t} L_{t}+\left(1-\tau_{p}\right)\left(r_{t}-\delta\right) W_{t}+T+W_{t}-C_{t} .
$$

Maximizing utility $\sum_{t=0}^{\infty} \beta^{t} u(C)$ subject to (14) provides the Ramsey rule.

$$
\frac{C_{t+1}}{C_{t}}=\left\{\beta\left[1+\left(1-\tau_{p}\right)\left(r_{t+1}-\delta\right)\right]\right\}^{1 / \sigma}
$$

Here $\beta<1$ is a constant discount factor reflecting time preference and $\sigma$ denotes the inverse of the intertemporal elasticity of substitution, which is assumed to be constant over time. 
2.3. Government and General Equilibrium. A part of revenue is not transferred back to households in form of either transfers or interest payments on government bonds. Using Ricardian equivalence the path of government debt necessary to balance the current budget is represented by a time series of transfers. The revenue not transferred back accounts for a constant fraction $g_{s}$ of GDP and is used unproductively for public consumption. Hence, given the paths of tax revenue and expenditure, the path of transfers (or the equivalent of government debt) is determined as the residual that ensures a balanced government budget at any point in time.

Aggregating (1) over firms provides economy-wide production $F\left(K_{t}, A_{t} L_{t}\right)$. From aggregate output a share of $\mu \Phi\left(\bar{\omega}_{t}\right)$ is lost in form of bankruptcy costs. From the remainder (i.e. the GDP) the government uses a share of $g_{s}$ for public consumption. The share left is disposable private income used for consumption and investment.

$$
F\left(K_{t}, A_{t} \cdot L_{t}\right)\left[1-\mu \Phi\left(\bar{\omega}_{t}\right)\right]\left(1-g_{s}\right)=C_{t}+K_{t+1}-(1-\delta) K_{t} .
$$

Inserting (13a) in (13b) and applying the no-arbitrage condition provides an implicit equation that determines the internal rate of return depending on the interest rate and the design of the fiscal system.

$$
\chi_{t}=\frac{1+\left\{\frac{\left(1-\tau_{r} z\right)\left(1-\tau_{p}\right)}{\left(1-\tau_{r}\right)\left(1-\tau_{c}\right)}\right\}\left(r_{t}-\delta\right)}{1+r_{t}-\delta} .
$$

The internal rate of return $\chi_{t}$ has to be larger than one for debt finance to be worthwhile implying that the fiscal policy term in curly brackets has to be larger than one for any solution, i.e.

Assumption 2.

$$
\frac{1-\tau_{p}}{1-\tau_{c}}>\frac{1-\tau_{r}}{1-\tau_{r} z}
$$

This is the familiar condition for the tax advantage of debt finance. It finds support in OECD (1991) for almost all OECD countries and will be assumed to be fulfilled throughout the article. ${ }^{7}$ From inspection of (17) we can already infer a central mechanism of the model. A higher tax advantage of debt implies that firms aspire a higher internal rate of return to equity. For that purpose they demand more debt and accept higher mark-ups and bankruptcy rates.

\section{The Co-evolution of Capital, Rates of Return, and Financial Structure}

As in the standard neoclassical model we obtain in any period $t$ a negative correlation between the interest rate and the stock of accumulated capital, $r^{\prime}\left(K_{t}\right)<0$. With contrast to the neoclassical

\footnotetext{
${ }_{7}$ For the U.S. Graham (2000) estimates a capitalized tax benefit of debt of about 10 percent of firm value.
} 
case, however, this correlation is not simply an artefact of capital's decreasing marginal product but generated by a more complicated mechanism that involves equilibria on factor and credit markets and is formally described by equations (3), (8), (9), and (17) which implicitly determine the set $\left(\omega_{t}, s_{t}, \chi_{t}, r_{t}\right)$ for given $K_{t}$ in period $t$. As in the standard model the fact that $r^{\prime}\left(K_{t}\right)<0$ is essential because it ensures existence, uniqueness, and saddle-point stability of the long-run equilibrium. We thus derive it successively.

Proposition 1. Default values and mark-ups are positively correlated.

$$
\bar{\omega}_{t}^{\prime}=\frac{\partial \bar{\omega}_{t}}{\partial s_{t}}>0
$$

Proof. Differentiate (9) implicitly and obtain that $\partial \bar{\omega}_{t} / \partial s_{t}>0$ requires $\phi^{\prime} f^{\prime}-\phi f^{\prime \prime}<0$. Insert (5) and write this condition as $(1-\Phi) \phi^{\prime}+\phi^{2}>0$, which is fulfilled because the hazard rate is increasing in $\bar{\omega}$ (Assumption 1).

With the notion of an implicit function $\bar{\omega}\left(s_{t}\right), \chi_{t}$ in (8) can be understood as a function of $s_{t}$.

Proposition 2. The correlation between internal rate of return and mark-up is positive.

$$
\frac{\partial \chi_{t}\left(s_{t}, \bar{\omega}\left(s_{t}\right)\right)}{\partial s_{t}}>0
$$

Proof. Compute the derivative $\partial \chi_{t} / \partial s_{t}=\left[\left(f^{\prime} \bar{\omega}^{\prime} s_{t}+f\right)(1-s g)+f s_{t}\left(g^{\prime} \bar{\omega}^{\prime} s_{t}+g\right)\right] /\left(1-s_{t} g\right)^{2}$. Use (7) to replace $g$ and $g^{\prime}$ and substitute $s$ from (9) to see that the numerator of this expression simplifies to $f\left(\bar{\omega}_{t}\right)>0$.

The result is immediately intuitive. A high internal rate of return reflects a high incentive for debt financed investment. The resulting high bankruptcy risk implies high costs of debt finance and a large mark-up on factor costs.

Proposition 3. The correlation between interest rate and mark-up is positive for any given set of taxes $\left(\tau_{r}, \tau_{p}, \tau_{c}, z\right)$ fulfilling Assumption 2.

$$
\frac{\partial s_{t}}{\partial r_{t}}>0
$$

Proof. $\partial s_{t} / \partial r_{t}=\left(\partial \chi_{t} / \partial r_{t}\right) /\left(\partial \chi_{t} / \partial s_{t}\right)$. Obtain $\partial \chi_{t} / \partial r_{t}>0$ from (17) and Assumption 2. The denominator is positive because of Proposition 2.

Again, the result is intuitive. A higher return on capital leads to larger investment for any given 
stock of equity. This in turn implies a higher leverage ratio and higher bankruptcy risk. Costs of debt finance are higher, implying a larger mark-up.

Proposition 4. The correlation between capital stock and interest rate is negative for any given set of taxes $\left(\tau_{r}, \tau_{p}, \tau_{c}, z\right)$ fulfilling Assumption 2.

$$
\frac{\partial r_{t}}{\partial K_{t}}<0
$$

Proof. Apply the implicit function theorem on (3), i.e. on $F_{K t}-s_{t} r_{t}=0$ and use Proposition 3 and $F_{K K t}<0$.

For an intuition of the mechanism imagine an economy below its long-run steady-state that accumulates capital (in case of technological progress at a rate higher than the steady-state rate of accumulation). As in the standard growth model more capital accumulation implies a tendency for productivity $F_{K}$ to fall. With contrast to the standard model this is not yet sufficient to claim decreasing interest rates, as evident from equation (3). In addition, capital accumulation lowers the value of equity capital and through this channel the incentive for firms to expand through costly debt finance. Firms thus require a smaller share of debt and contract with banks at lower $\bar{\omega}$, i.e. $\partial \bar{\omega} / \partial K<0$. A lower default value $\bar{\omega}$ implies a lower markup rate $s$ and lower internal rate of return $\chi$. This in turn necessarily implies a lower interest rate $r$ according to (17) and Proposition 3. The result that both, $r_{t}$ and $s_{t}$, are decreasing with capital accumulation reflects the lower overall scarcity of capital.

\section{Taxation, Corporate Finance, and Growth}

This section investigates the steady-state, comparative statics of tax reforms, and adjustment dynamics for the finance-augmented growth model. General productivity $\left(A_{t}\right)$ is allowed to grow at an exogenous constant rate $\gamma$. Endogenous growth is investigated later, in Section 6 . Let $k_{t}$ and $c_{t}$ denote capital and consumption in efficiency units $k_{t} \equiv K_{t} /\left(A_{t} L_{t}\right)$ and $c_{t} \equiv C_{t} /\left(A_{t} L_{t}\right)$. Using the new notation, Ramsey rule (15) and GDP equation (16) are rewritten as follows.

$$
\begin{aligned}
& k_{t+1}=\frac{1}{1+\gamma}\left\{F\left(k_{t}, 1\right)\left[1-\mu \Phi\left(\bar{\omega}\left(k_{t}\right)\right)\right]\left(1-g_{s}\right) k_{t}+(1-\delta) k_{t}-c_{t}\right\} \\
& c_{t+1}=\frac{1}{1+\gamma}\left\{\beta\left[1+\left(1-\tau_{p}\right)\left(r\left(k_{t+1}\right)-\delta\right)\right]\right\}^{1 / \sigma} \cdot c_{t} .
\end{aligned}
$$


The reduced form of the model consists of the above two-dimensional system of difference equations for $k$ and $c$ and a system of equations (3), (8), (9), and (17) that - together with the distribution function for $\omega$-implicitly determines $r\left(k_{t}\right)$ and $\bar{\omega}\left(k_{t}\right)$ (as well as the equilibrium values for $\chi\left(k_{t}\right)$ and $s\left(k_{t}\right)$ as derived in the Section 3$) . k_{t}$ is the unique state variable of the reduced form.

Equation (18b) shows that at a steady-state the net interest rate equals the growth adjusted rate of time preference $1 / \beta-1$.

$$
\left(1-\tau_{p}\right)\left(r^{*}-\delta\right)=\frac{(1+\gamma)^{\sigma}}{\beta}-1
$$

With $r^{*}$ fixed we to obtain from (17) the internal rate of return at the steady-state as uniquely determined by parameters of time preference and various fiscal policy measures.

$$
\chi^{*}=\frac{1+\left\{\frac{\left(1-\tau_{r} z\right)\left(1-\tau_{p}\right)}{\left(1-\tau_{r}\right)\left(1-\tau_{c}\right)}\right\}\left(r^{*}-\delta\right)}{1+r^{*}-\delta} \ldots
$$

This result can be exploited to derive the comparative statics of fiscal policy reforms.

Proposition 5. In the finance-augmented neoclassical growth model a corporate tax cut has the following set $\mathbb{A}$ of long-run consequences.

$\mathbb{A}=\{$ (i) Lower internal rate of return on equity, (ii) lower critical value of default (i.e. lower bankruptcy rate), (iii) lower mark-up on factor costs, (iv) higher equity ratio, (v) higher capital stock, (vi) higher wages, and (vii) higher consumption\}.

Proof. Inspect (20) to obtain $\partial \chi^{*} / \partial \tau_{r}>0$. Then, conclude (ii) from Proposition 1 and (iii) from Proposition 2. The equity ratio is given by $f(\omega)$ with $f^{\prime}>0$ from (5) which implies (iv). Because $s^{*}$ decreases and $r^{*}$ remains constant, $F_{K}$ must decrease for (3) to be fulfilled. This implies (v). Due to the neoclassical features of production a higher capital stock implies higher marginal product of labor, $F_{L}>0$. Together with a lower mark-up this implies increasing wages because of (3). Finally, obtain from $(18) c^{*}=F\left(k^{*}\right)(1-\mu \Phi(\bar{\omega}))\left(1-g_{s}\right) k^{*}-(\delta+\gamma) k^{*}$. This expression must increase because of larger $k$ and lower $\bar{\omega}$.

Note that these results are qualitatively different from those suggested by the standard Ramsey growth model. In the standard model any policy that leaves the real interest rate unchanged has no long-run effects. Here, re-adjustment of investment and finance decisions of corporate firms causes a multitude of real effects. A lower tax on retained earnings reduces the tax advantage of debt finance and lowers debt demand. A lower optimal $\chi^{*}$ reflects this adjustment of capital 
structure towards a higher equity ratio. Less leverage implies less bankruptcy risk, and firms and banks contract at a lower $\bar{\omega}$. Lower bankruptcy rates and lower agency costs imply a smaller mark-up on factor costs. Through this credit channel the corporate tax cut has real consequences although the real interest rate remains constant. Because of lower costs of finance (reflected by a smaller $s$ ), capital is employed more efficiently than before the reform and firms raise investment and capital stock. Formally, $F_{K}$ decreases simultaneously with $s$ in equation (3). With rising $k$, output, wages and consumption increase. The reform furthermore entails a positive effect of second order on production and consumption caused by lower probability of bankruptcy. Formally, $\mu \Phi(\bar{\omega})$, in (18a) decreases.

Analogously to Proposition 5 we obtain the following results.

Proposition 6. In the finance-augmented neoclassical growth model a cut in capital gains taxes or an increase of tax allowances implies set $\mathbb{A}$ of long-run economic consequences.

The proof computes the derivatives of $\chi^{*}$ in (20) with respect to $\tau_{c}$ and $z$ and proceeds as the proof for Proposition 5.

Proposition 7. In the finance-augmented neoclassical growth model a cut in taxes on private capital income leads to a higher internal rate of return on equity, a higher mark-up on factor costs, a higher critical value of default, and a lower equity ratio.

Proof. Obtain $\partial \chi^{*} / \partial \tau_{p}<0$ from (20). A lower private income tax decreases the incentive for equity financed investment and increases the tax advantage of debt finance. Higher demand for debt is reflected by a higher internal rate of return on equity, a higher mark-up (Proposition 2), and a higher critical value for default (Proposition 1), which implies a lower equity ratio.

Interestingly, the conclusion derived from the standard neoclassical growth model that a tax cut for private capital income leads to a larger capital stock and more income per capita cannot generally be drawn. The savings channel through which this effect operates is also at work in the present model. Here, however, this is not yet sufficient to conclude a higher capital stock, since $r=F_{k} / s$, and it has just been shown that lower interest rates $\tau_{p}$ cause the mark-up $s$ to rise. In other words, the mechanism known as the financial accelerator dampens the expansive effect of capital income tax cuts. It operates as a financial decelerator in the present framework. The provoked increasing tax advantage of debt finance leads to higher bankruptcy rates and higher 
costs of debt finance and - taken for itself - to lower capital stock and consumption. Numerical calibration is required to determine which effect dominates.

Finally, consider adjustment dynamics.

Proposition 8. Consider a growing economy in the finance-augmented neoclassical growth model $\left(k<k^{*}\right)$. As the economy develops firms become less leveraged, and bankruptcy rates and mark-ups decrease.

Proof. In the Appendix it is shown that the steady-state is a saddle-point. Transitional dynamics are uniquely determined by the stable arm along which $c_{t}$ and $k_{t}$ rise for adjustment from below steady-state values. Noting that $k$ is rising, apply Proposition 1 to 4.

The equity ratio of the average firm rises as the economy develops and capital productivity and interest rates decrease. Consequently, banks demand lower risk premia and contract at a lower value $\bar{\omega}_{t}$ with firms. The mark-up $s_{t}$ decreases at higher stages of development. From decreasing bankruptcy rates along the adjustment path, however, we cannot conclude overall falling costs debt finance. Of the total costs of debt finance given by $\mu \Phi\left(\bar{\omega}_{t}\right) \cdot F\left(K_{t}, A_{t} L_{t}\right)$ the first term $\Phi\left(\bar{\omega}_{t}\right)$ unambiguously decreases because of lower risk of bankruptcy. The second term, total size of production $F\left(K_{t}, A_{t} L_{t}\right)$, i.e. the input bill, increases. At higher stages of development the representative firm is bigger. Because total costs are a compound of (decreasing) individual risk and (rising) firm size, the overall affect is ambiguous.

\section{Quantitative Effects of Policy Reforms}

In order to investigate the quantitative effects of tax reforms and to resolve the remaining ambiguities we consider a numerical calibration of the model with U.S. data. For that purpose production is assumed to be of Cobb-Douglas-type with capital share $\alpha$. Parameters originating from the standard growth model are calibrated in accordance with the real business cycle literature. The benchmark case assumes $\alpha=0.36, \delta=0.08, \beta=0.098$, and adjusts $\sigma$ to support a a longrun growth rate of 1.5 percent per year, i.e. $\sigma=1.9$. These values imply a net interest rate of 5 percent. The remaining parameters are determined corresponding to the studies of Gordon and Lee (2001) and Carlstrom and Fuerst (2001). Gordon and Lee investigate the nexus between corporate taxation and leverage and estimate that a five percentage increase in $\left(\tau_{p}-\tau_{r}\right)$ raises the debt ratio by about 1.8 percentage points. From their study we take $\tau_{r}=0.45$ (the average corporate tax 
rate for medium sized firms) and $\tau_{p}=0.245$. The tax on capital gains is an effective rate and following Ballard et al. (1985) it is set to one fourth of the statutory tax rate as approximation, i.e. $\tau_{c}=0.05$. For the share of investment that depreciates immediately we assume $z=0.25$ (See Sinn, 1987, Ch. 3.1.3). The government share of GDP, $g$, is set to 0.14.

As in Carlstrom and Fuerst (2001) and related real business cycle literature productivity shocks are assumed to be log-normally distributed. With contrast to this literature, however, the internal rate of return cannot be set arbitrarily (through time-preference of entrepreneurs). It is endogenously determined according to (20) by the net interest rate and the design of tax rates. For benchmark values we obtain $\chi=1.0175$. Given one degree of freedom less, we take the bankruptcy rate from Carlstrom and Fuerst's calibration $(\Phi(\bar{\omega})=0.04$ per year) and set the equilibrium debt ratio, $b \equiv 1-f(\omega)$, to 0.194 , the weighted average for the sample of U.S. corporations in Gordon and Lee's study. Risk premium, bankruptcy costs, and the parameters of the log-normal distribution are endogenously determined. For the benchmark parameterization we obtain a default value $(\bar{\omega})$ of 0.196 , a standard deviation of 0.76 , a bankruptcy cost parameter of 0.029 , and a risk premium of 1.57 percent. These values imply a mark-up of 1.0153.

The first row in Table 2 shows results for a 5 percentage point cut in the average tax rate on private capital income. The policy raises the tax advantage of debt finance, and the optimal internal rate of return on equity increases by about 0.4 percentage points. The higher share of debt increases default risk, and firms and banks contract on a higher default value. $\bar{\omega}$ rises by about 3 percentage points. The new debt contract implies a higher bankruptcy rate by about 2 percentage points, and a higher risk premium, which increases by 0.78 percentage points. The debt ratio of the average firm raises by 3.1 percentage points.

The rising cost of debt has - by itself - a negative effect on investment. This credit-channel effect, however, is comparatively small. It is dominated by the expansive effect that operates through lower net interest rates and higher savings. Investment rises by about 0.6 percentage points and the capital stock is 4 percent higher than before the reform. Output and consumption are subject to a second negative effect caused by higher agency costs from increasing leverage. These costs become visible through a higher mark-up, which increases by 0.31 percentage points. In the new steady-state consumption lies 0.4 percent above its pre-reform value.

Adjustment dynamics are shown by solid lines in Figure 1. Increasing demand for capital raises interest rates on impact and consumption lies below its pre-reform value for about the next 20 years 
following the reform. Figure 1 also reveals an overshooting of financial variables. On impact the debt ratio lies by about 4 percent above its pre-reform value and adjusts to the new steady-state value from above. The same can be observed for bankruptcy rates, which rise to 2.8 percent above the pre-reform value shortly after the tax cut. These negative transitional dynamics question the positive effect of the reform. Following the Lucas (1990) methodology the welfare gain from the reform is computed as the constant relative increase in consumption that equates intertemporal utility from remaining in the pre-reform state and switching to the consumption path after the reform. We employ the method of Brunner and Strulik $(2002,2004)$ to take adjustment dynamics of the non-linearized system into account. The resulting welfare gain is calculated to be -0.12 percent implying that the reform actually causes a small welfare loss.

Table 2: Effects of Tax Reforms: Neoclassical Growth Model

\begin{tabular}{|c|c|c|c|c|c|c|c|c|c|c|}
\hline & $\chi$ & $\bar{\omega}$ & $s$ & $r_{L}$ & $\Phi$ & $b$ & $i$ & $k$ & $c$ & $L$ \\
\hline & \multicolumn{10}{|c|}{ Private Capital Income Tax Cut by 5 Percentage Points } \\
\hline benchmark & 0.39 & 3.23 & 0.31 & 0.78 & 2.05 & 3.1 & 0.59 & 4.0 & 0.40 & 0.00 \\
\hline no debt & 0.00 & 0.00 & 0.00 & 0.00 & 0.00 & 0.0 & 0.68 & 4.6 & 0.52 & 0.00 \\
\hline$\eta=1.0$ & 0.39 & 3.23 & 0.31 & 0.78 & 2.05 & 3.1 & 0.59 & 4.0 & 0.40 & 0.48 \\
\hline$\sigma=1.0$ & 0.28 & 3.23 & 0.22 & 0.72 & 2.05 & 3.1 & 0.55 & 3.3 & 0.15 & 0.53 \\
\hline$\beta=0.99$ & 0.32 & 3.23 & 0.25 & 0.74 & 2.05 & 3.1 & 0.58 & 3.6 & 0.24 & 0.52 \\
\hline$b=0.25$ & 0.39 & 3.19 & 0.29 & 0.62 & 1.81 & 3.0 & 0.60 & 4.1 & 0.41 & 0.50 \\
\hline \multirow[t]{2}{*}{$\Phi(\bar{\omega})=0.03$} & 0.39 & 2.62 & 0.31 & 0.52 & 1.38 & 2.5 & 0.59 & 4.2 & 0.39 & 0.47 \\
\hline & \multicolumn{10}{|c|}{ Corporate Tax Cut by 5 Percentage Points } \\
\hline benchmark & -0.56 & -4.18 & -0.46 & -0.77 & -2.05 & -4.1 & 0.11 & 0.72 & 0.17 & 0.00 \\
\hline$b=0.25$ & -0.56 & -4.42 & -0.43 & -0.65 & -1.94 & -4.3 & 0.10 & 0.67 & 0.17 & 0.36 \\
\hline \multirow[t]{2}{*}{$\Phi(\bar{\omega})=0.05$} & -0.56 & -4.72 & -0.46 & -1.00 & -2.67 & -4.6 & 0.11 & 0.72 & 0.18 & 0.37 \\
\hline & \multicolumn{10}{|c|}{ Corporate \& Private Income Tax Cut by 5 Percentage Points } \\
\hline \multirow[t]{2}{*}{ benchmark } & -0.17 & -1.30 & -0.14 & -0.27 & -0.71 & -1.2 & 0.70 & 4.8 & 0.60 & 0.00 \\
\hline & \multicolumn{10}{|c|}{ Capital Gains Tax Cut by 50 Percent } \\
\hline benchmark & -0.20 & -1.56 & -0.17 & -0.32 & -0.85 & -1.5 & 0.04 & 0.26 & 0.07 & 0.00 \\
\hline
\end{tabular}

Benchmark parameters: $\alpha=0.36, \beta=0.98, \sigma=1.9, \eta=0, \gamma=0.015, \delta=0.08, \tau_{r}=0.45$, $\tau_{p}=0.245, \tau_{c}=0.05, z=0.25, g=0.14, \Phi=0.04, b \equiv(1-f(\bar{\omega})=0.194$, implying $r_{L}=0.157, \mu=0.029, \sigma_{\omega}=0.76$. The investment rate $I / Y$ is denoted by $i$. Effects on $k$ and $c$ are measured in percent deviation from pre-reform equilibrium, e.g. $\Delta k / k \cdot 100$, effects on all other variables are measured in percentage point deviation, e.g. $\Delta \chi \cdot 100$.

The second row in Table 2 shows results for an otherwise identical economy without corporate sector and without debt finance, i.e. for the standard textbook model. In this case, $\mu=0, s=1$. We see that the textbook model slightly overestimates the effect of the reform on investment and consumption because it neglects the credit channel. Dashed lines in Figure 1 show that the 
textbook model slightly overestimates the negative initial impact of the reform and the speed of adjustment towards the new steady-state.

To consider endogenous labor supply instantaneous utility is reformulated. $U_{t}=\left(C_{t} x_{t}^{\eta}\right)^{1-\sigma} /(1-$ $\sigma)$, where $x_{t}$ denotes leisure. From the new first order conditions, optimal leisure is derived as

$$
x_{t}=\frac{\eta s_{t} c_{t}}{\left(1-\tau_{w}\right)(1-\alpha) k_{t}^{\alpha}}
$$

We set $\tau_{w}$ to the value of 0.36 , estimated by Carey and Tchilinguirian (2000) as the average effective tax rate on labor income. Total time is normalized so that in pre-reform equilibrium individuals spend one third of their time working. We set $\eta=1.0$. The implied Frisch elasticity of labor supply of 1.0 is close to the empirical estimates in Kimball and Shapiro (2003) and lies in the middle of the range of values used by other calibration studies.

Figure 1. Real and Financial Adjustment Dynamics After Capital Tax Reform
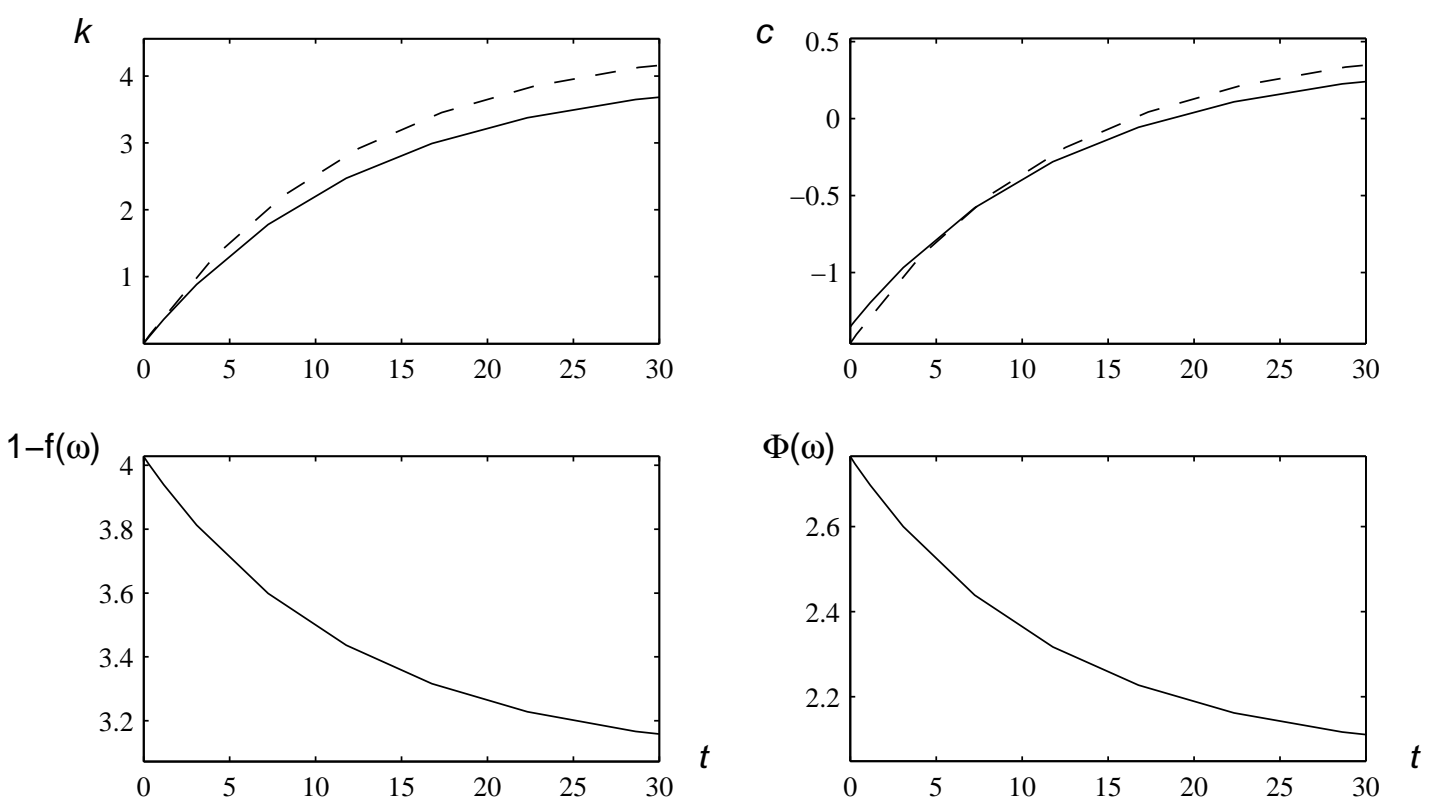

Capital tax cut of 5 percentage points. For capital stock and consumption: deviation from pre-reform equilibrium in percent. For the debt rate, $1-f(\bar{\omega})$, and the bankruptcy rate, $\Phi(\bar{\omega})$ : deviation from pre-reform values in percentage points.

The introduction of endogenous labor supply leaves the finance and investment decision of firms unaltered. Total consumption per efficiency unit $(c \cdot L)$ rises by about 1.8 percent above its prereform value. This relatively strong change of consumption is mainly driven by higher employment. Labor supply increases by about half a percentage point. 
Subsequent rows of Table 2 provide some robustness checks. Results are most sensitive to parameters that change the net interest rate or the terms of the debt contract. Row 3 and 4 show results for a change of preferences. If $\sigma=1$ (implying a lower net interest rate of 3.5 percent) the effect of the reform on lending costs is somewhat smaller leading to a less expansive effect on investment and consumption. The same applies if the discount factor is 0.99 implying a lower net interest rate of 4 percent.

The next row indicates that results are very robust against the assumption of higher pre-reform leverage. The value of 0.25 coincides with the unweighted mean of the debt asset ratio in Gordon and Lee's sample. Results change most for alternative bankruptcy rates. This is demonstrated in the final row of the first part in Table 2. When the pre-reform bankruptcy rate is 3 percent (instead of 4) the impact of the tax cut on risk premium, bankruptcy rate, and leverage is also about one fourth smaller. The calculated change of 2.5 percentage points for the debt ratio comes closer to the predicted value of 1.8 from Gordon and Lee's study. This overall lower response of capital structure, however, causes relatively small changes of real effects of the reform.

Generally we conclude that capital tax reforms are followed by comparatively large adjustments of capital structure. Against this background real effects derived in addition to the standard interest-rate-effect are small. For example, the estimated effect of the reform on consumption depends more heavily on whether $\sigma$ equals one or two (values that are both frequently used in model calibration) than on whether a corporate sector and financial decisions of firms are taken into account or not.

The second part of Table 2 shows results for a 5 percentage point cut in the corporate tax rate. By construction the standard Ramsey model (without corporate sector) cannot identify any effect of this policy. Here, the corporate finance model reveals strong reactions of financial variables. Caused by the vanishing tax advantage of debt financing, leverage decreases by about 4 percentage points and the bankruptcy rate decreases by about 2 percentage points. Because of decreasing default risk, banks and firms contract on a lower $\bar{\omega}$. Lower costs of debt are carried forward to households by lower mark-ups on factor costs. Through this credit channel the policy affects the real economy. Although the change of investment and capital stock is small, the effect on consumption is relatively large. Consumption lies about 0.17 percent above its pre-reform value. This time, the financial accelerator lives up to his name. All effects of the reform operate towards increased efficiency. 
It is interesting to note that the two tax reforms affect bankruptcy rates in opposite directions by exactly the same absolute magnitude. From this observation one might be tempted to conclude that a simultaneous cut in both tax rates leaves bankruptcy rates and the finance side of the model unaffected. The third part of Table 2 shows that this conclusion is not valid. Effects from corporate tax reform dominate. The model predicts a 1.5 percentage point decrease in the debt ratio accompanied by an 0.7 percentage point decrease in bankruptcy rates.

Finally, we consider a reduction of the statutory tax on capital gains from 20 to 10 percent, i.e. a reduction of the effective tax from 5 to 2.5 percent. As for the corporate tax case the reform provokes real effects through adjustment of financial decisions. These adjustments, however, are relatively small because the effective rate is already low. The benchmark model predicts that the lower tax advantage leads to a decrease in the debt ratio by 1.5 percentage points. The mark-up decreases by 0.17 percentage points. The increasing efficiency of factor use raises consumption by 0.07 percent above its pre-reform value.

\section{Tax Reform, Corporate Finance, and Endogenous Growth}

This section investigates the impact of tax reforms on human capital driven growth in a Lucas (1990)-type model. In a period $t$ households supply a fraction $u_{t}$ of their human capital $H_{t}$ on the labor market (i.e. $L_{t} \equiv u_{t} H_{t}$ ), invest a fraction $v_{t}$ in education, and enjoy the remaining fraction $x_{t}$ as leisure. Human capital accumulates according to a linear production function. This adds the following constraints to the households' problem.

$$
H_{t}=\xi v_{t} H_{t}+\left(1-\delta_{H}\right) H_{t}, \quad 1-x_{t}-u_{t}-v_{t}=0
$$

The parameter $\xi$ determines productivity of the schooling sector and $\delta_{H}$ is the depreciation rate of human capital. The first order conditions can be summarized by the Ramsey rule, leisure demand (21), and the following no-arbitrage condition for investment in human and physical capital.

$$
\frac{w_{t+1}}{w_{t}}=\frac{1+\left(1-\tau_{p}\right)\left(r_{t+1}-\delta\right)}{\xi\left(u_{t+1}+v_{t+1}\right)+\left(1-\delta_{H}\right)}
$$

Note that wages are paid per unit of human capital and are constant in the long-run. In a steadystate, consumption, and physical and human capital grow at an equal rate. Equation (22) shows that this growth rate depends only on time devoted to schooling, $v^{*}$.

As for the neoclassical case an assessment of a capital tax cut can be subdivided into an interest 
rate effect (which operates also in the standard Lucas growth model) and an (additional) cost of finance effect. A cut in $\tau_{p}$ raises the net interest rate and makes capital accumulation more attractive. As shown by the no-arbitrage rule (23) the policy also raises the incentive to accumulate human capital. Rising capital accumulation implies higher wages per unit of human capital and by itself - a higher incentive to allocate more time to work. Hence, the overall interest rate effect on growth depends on whether the labor supply effect or the schooling effect dominates. If the denominator on the right hand side of (23) adjusts to raising interest rates mainly by $u_{t}$, growth effects will be small. Relatively large effects on growth result if mainly $v_{t}$ adjusts. Equilibrium labor supply is obtained as

$$
\xi u^{*}=\beta^{-\sigma}\left[\xi v^{*}+\left(1-\delta_{H}\right]^{\sigma}-\left[\xi v^{*}+\left(1-\delta_{H}\right)\right] .\right.
$$

From this we see that the effect of the reform on employment depends on the intertemporal elasticity of substitution and will be small for small $\sigma$.

In the corporate finance model the interest rate effect on growth is weakened through the credit channel. Firms react to an improving tax advantage by demanding more debt and contracting with banks on a higher $\bar{\omega}$. Resulting higher bankruptcy rates and higher agency costs carry over to households through increasing mark-ups on factor costs.

For a corporate tax cut we expect a growth effect that is not observable within the standard Lucas growth model. Driven by the decreasing tax advantage, firms demand less debt and contract with banks on lower $\bar{\omega}$ 's. Bankruptcy rates and mark-ups are lower than before the reform. Because of lower mark-ups $(s)$ the purchasing power of wages $\left(w_{t}=(1-\alpha) k_{t}^{\alpha} / s_{t}\right)$ is higher and households devote less time to leisure. This can be observed from inspection of (21). Again, the growth effect depends on whether less leisure implies mainly more employment or longer education.

In order to make the calibration comparable to the neoclassical model we require that households generate an annual growth rate of 1.5 percent in the pre-reform state for benchmark parameter values. This requirement leads to a loss of one degree of freedom. The value for $\eta$ is now predetermined at 0.82 . We set $\delta_{H}$ to one percent and obtain $\xi$ endogenously so that households continue to allocate one third of their time to employment. This provides $\xi=0.105$. All other parameter values are taken from calibration of the neoclassical growth model.

Table 3 shows the evaluated growth effects from tax reforms. The benchmark calibration suggest a change of both employment and schooling by 0.1 percentage points and a 0.011 percentage point 
Table 3: Effects of Tax Reforms: Endogenous Growth Model

\begin{tabular}{|c|c|c|c|c|c|c|c|c|c|c|c|}
\hline & $\chi$ & $\bar{\omega}$ & $s$ & $r_{L}$ & $\Phi$ & $b$ & $i$ & $k$ & $u$ & $v$ & $g_{c}$ \\
\hline \multicolumn{12}{|c|}{ Private Capital Income Tax Cut by 5 Percentage Points } \\
\hline benchmark & 0.39 & 3.23 & 0.31 & 0.78 & 2.05 & 3.1 & 0.57 & 3.7 & 0.10 & 0.10 & 0.011 \\
\hline no debt & 0.00 & 0.00 & 0.00 & 0.00 & 0.00 & 0.0 & 0.65 & 4.1 & 0.15 & 0.15 & 0.016 \\
\hline$\sigma=1$ & 0.28 & 3.23 & 0.22 & 0.72 & 2.05 & 3.1 & 0.56 & 3.1 & 0.00 & 0.22 & 0.013 \\
\hline$\beta=0.99$ & 0.32 & 3.23 & 0.25 & 0.74 & 2.05 & 3.1 & 0.56 & 3.3 & 0.09 & 0.09 & 0.007 \\
\hline$b=0.25$ & 0.39 & 3.19 & 0.29 & 0.62 & 1.81 & 3.1 & 0.58 & 3.7 & 011 & 0.11 & 0.011 \\
\hline$\Phi(\bar{\omega})=0.03$ & 0.39 & 2.62 & 0.31 & 0.52 & 1.38 & 2.5 & 0.57 & 3.7 & 0.10 & 0.10 & 0.010 \\
\hline \multicolumn{12}{|c|}{ Corporate Tax Cut by 5 Percentage Points } \\
\hline benchmark & -0.56 & -4.18 & -0.46 & -0.77 & -2.05 & -4.1 & 0.09 & 0.45 & 0.08 & 0.08 & 0.008 \\
\hline \multicolumn{12}{|c|}{ Capital Gains Tax Cut by 50 Percent } \\
\hline benchmark & -0.20 & -1.56 & -0.17 & -0.32 & -0.85 & -1.5 & 0.03 & 0.13 & 0.03 & 0.03 & 0.004 \\
\hline
\end{tabular}

Benchmark parameters as for Table 2, except $\eta=0.82, \xi=0.105, \delta_{h}=0.01$. Change of $k$ is measured in percent deviation from pre-reform equilibrium, effects on all other variables are measured in percentage point deviation.

increase in the long-run growth rate (i.e. from 1.50 to 1.511 percent). As suggested by earlier studies the growth effect of taxation is small (See e.g. Lucas, 1990, Mendoza et al., 1997). Results obtained for an otherwise identical model without corporate sector are presented in the second row. We see that even the small growth effect calculated for the standard model turns out as an overestimation when corporate finance is taken into account.

Measured against its comparatively small effect on investment the corporate tax cut has a larger impact on growth because of the accelerating effect of adjustment of capital structure. Yet, in absolute magnitude the growth effect is rather small. This is even more true for the capital gains tax cut for which the calculated effect on growth is negligible.

\section{Conclusion}

This article has investigated the credit channel of capital taxation. For that purpose a neoclassical growth model has been augmented by corporate firms, financial intermediation, and a set of tax rates on corporate and private income. Despite its complexity the model can still be analyzed analytically. It predicts an expansive effect of corporate tax cuts that operates through the credit channel. A lower corporate tax reduces the tax advantage of debt finance. Given the resulting lower demand for debt, firms contract with banks on lower default values. Because of lower bankruptcy rates and agency costs, mark-ups on factor costs are lower, reflecting the efficiency gain 
from the reform that leads to an expansion of investment, capital stock, consumption, and growth (if the latter is endogenously explained).

Analogous reasoning derives a negative effect of tax cuts on private capital income through the credit channel. The credit-channel effect works against the usually obtained expansive interest rate effect so that clear-cut conclusions about the efficiency gain from capital tax reductions can no longer be drawn analytically. A calibration with U.S. data shows that the positive interest rate effect dominates. The calibration reveals also strong and overshooting effects of capital tax reforms on the financial side of the economy, i.e. on debt ratios, bankruptcy rates, lending rates, and agency costs. The transmission through the credit channel to the real side of the economy, i.e. on investment and growth, however, is relatively small.

There are several possible extensions of the basic framework comprehensible. One is a more active role of entrepreneurs. This article has argued in favor of an institutional explanation of financial structure that replaces an behavioral explanation based on high time preference or short life of entrepreneurs. The focus on institutions and the assumption of a homogenous population has surely downplayed the role of entrepreneurs for economic growth. It would be interesting to re-introduce some heterogeneity into the current framework e.g. with respect to risk taking or the initial endowment with human capital. It could then be investigated how the tax system influences entrepreneurial activity and whether the small impact of corporate taxation on growth is amplified through this channel as argued by Lee and Gordon (2005).

A second actor for which a more active role would be desirable are banks. A more explicit modelling of banks, for example through an integration of the current approach with Diaz-Giminez et al.'s (1992) theory of banking in general equilibrium, would allow to investigate an interaction of fiscal and monetary policy. Whether and how the impact of tax reforms through the credit channel would be modified in such an environment is an interesting project for future research. 


\section{Appendix: Stability analysis}

Consider the dynamic system (18). Linearizing around the steady-state we get,

$$
J^{L}\left(k^{*}, c^{*}\right)\left(\begin{array}{c}
k_{t+1}-k^{*} \\
c_{t+1}-c^{*}
\end{array}\right)=J^{R}\left(k^{*}, c^{*}\right)\left(\begin{array}{c}
k_{t}-k^{*} \\
c_{t}-c^{*}
\end{array}\right) .
$$

The Jacobian matrices at the left and right hand side are

$$
J^{L} \equiv\left(\begin{array}{cc}
1 & 0 \\
J_{21}^{L} & \frac{1}{1+\gamma}
\end{array}\right), \quad J^{R} \equiv\left(\begin{array}{cc}
J_{11}^{R} & -\frac{1}{1+\gamma} \\
0 & \frac{1}{1+\gamma}
\end{array}\right) .
$$

where

$$
\begin{aligned}
& J_{21}^{L} \equiv-\frac{1}{\sigma}\left\{\beta\left[1+\left(1-\tau_{p}\right)\left(r\left(k^{*}\right)-\delta\right)\right]\right\}^{-\frac{1}{\sigma}-1} \cdot\left(1-\tau_{p}\right) \cdot \frac{\partial r\left(k^{*}\right)}{\partial k}>0, \\
& J_{11}^{R} \equiv\left\{f^{\prime}\left(k^{*}\right)\left[1-\mu \Phi\left(\bar{\omega}\left(k^{*}\right)\right)\right]-f\left(k^{*}\right) \mu \phi\left(\bar{\omega}\left(k^{*}\right)\right) \cdot \frac{\partial \bar{\omega}\left(k^{*}\right)}{\partial k}\right\} \cdot\left(1-g_{s}\right)+(1-\delta)>0 .
\end{aligned}
$$

Positivity of $J_{21}^{L}$ follows from Proposition 4. Positivity of $J_{11}^{R}$ follows from $f^{\prime}(k)>0$ and $\partial \bar{\omega} / \partial k<0$ by application of Proposition 1 to 4.

The solved linearized system reads

$$
\left(\begin{array}{c}
k_{t+1}-k^{*} \\
c_{t+1}-c^{*}
\end{array}\right)=J \cdot\left(\begin{array}{c}
k_{t}-k^{*} \\
c_{t}-c^{*}
\end{array}\right), \quad J \equiv\left(J^{L}\left(k^{*}, c^{*}\right)\right)^{-1} \cdot J^{R}\left(k^{*}, c^{*}\right) .
$$

Stability is determined by the eigenvalues, $\lambda_{1}$ and $\lambda_{2}$, of matrix $J$. It is straightforward to calculate

$$
\begin{gathered}
\lambda_{1}+\lambda_{2}=\operatorname{tr}(J)=\frac{J_{11}^{R}}{1+\gamma}+J_{21}^{L}>0 \\
\lambda_{1} \cdot \lambda_{2}=\operatorname{det}(J)=\frac{J_{11}^{R}}{1+\gamma}>0 .
\end{gathered}
$$

Conclude from $\operatorname{det}(J)>0$ that both eigenvalues have the same sign and thus from $\operatorname{tr}(J)>0$ that both are positive. Next, evaluate the characteristic polynomial $\lambda^{2}-\operatorname{tr}(J) \lambda+\operatorname{det}(J)$ at $\lambda=1$ :

$$
1-\operatorname{tr}-\operatorname{det}(J)=-J_{21}^{L}<0 .
$$

Conclude from the fact that the characteristic polynomial assumes the value of zero at $\lambda=\lambda_{1}$ and at $\lambda=\lambda_{2}$ and a negative value at $\lambda=1$ that one eigenvalue, $\lambda_{1}$, is smaller than 1 and the other, $\lambda_{2}$, is larger than 1 . Thus the equilibrium is a saddlepoint.

For analysis of global stability, conclude from (18) that the isocline where $\Delta c_{t} \equiv c_{t+1}-c_{t}=0$ is given by the horizontal curve

$$
r\left(k^{*}\right)=\left[\frac{(1+\gamma)^{\sigma}}{\beta}-1\right] /\left(1-\tau_{p}\right)+\delta .
$$

Use Proposition 4 to conclude that from $k>k^{*}$ follows $r<r^{*}$ and thus $\Delta c_{t}<0$. Thus, in the phase diagram of Figure 2 the arrows of motion point towards smaller $c_{t}$ to the right of $k^{*}$ and - analogously the arrows of motion point towards larger $c_{t}$ to the left of $k^{*}$.

The $\Delta k_{t}=0$-isocline is computed from (18) as

$$
c_{t}=f\left(k_{t}\right)\left[1-\mu \phi\left(\bar{\omega}_{t}\right)\right]\left(1-g_{s}\right)-(\gamma+\delta) k_{t}
$$

with slope

$$
\frac{\partial c_{t}}{\partial k_{t}}=\left\{f^{\prime}\left(k_{t}\right)\left[1-\mu \Phi\left(\bar{\omega}_{t}\right)\right]-f\left(k_{t}\right) \mu \phi\left(\bar{\omega}_{t}\right) \cdot \frac{\partial \bar{\omega}_{t}}{\partial k_{t}}\right\}\left(1-g_{s}\right)-(\gamma+\delta) .
$$

Use the fact that $\partial \bar{\omega} / \partial k<0$ from Proposition 1 to 4 . Thus $\Phi(\bar{\omega})$ approaches one for $k \rightarrow 0$ and zero 
Figure 2. The Credit Channel of Tax Policy: Phase Diagram

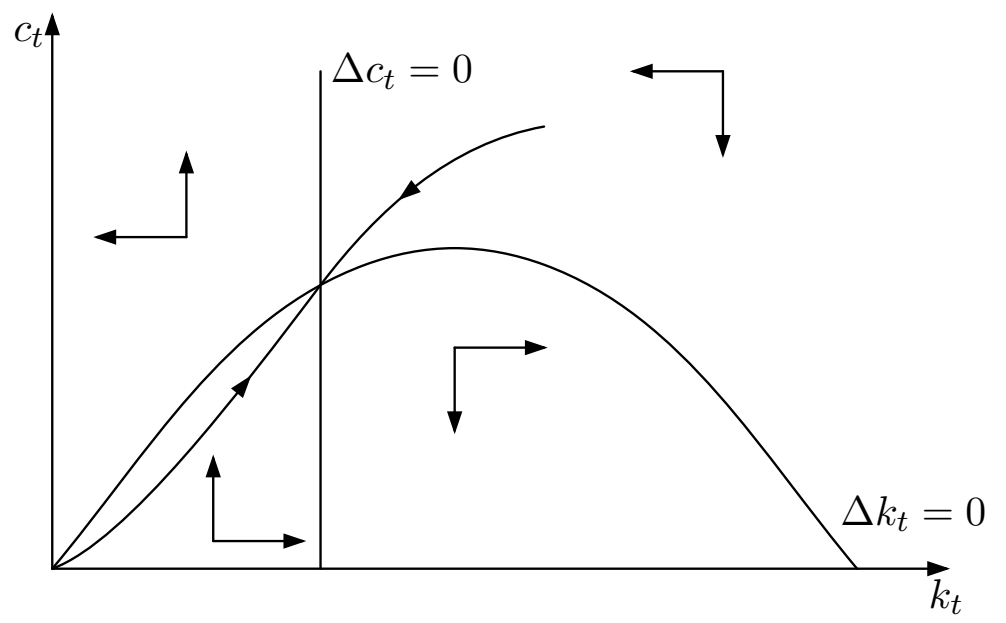

for $k \rightarrow \infty$. Since it follows from the Inada conditions that $f^{\prime}(k)$ approaches zero for $k \rightarrow \infty$ and $f^{\prime}(k)$ approaches infinity for $k \rightarrow 0$, the $\Delta k_{t}=0$-curve rises with infinite slope from the origin, reaches a finite maximum and falls to zero at finite $k_{t}$ as shown in Figure 2. Below the curve consumption is less than the value that supports $\Delta k_{t}=0$ and thus the arrows of motion point towards larger $k_{t}$. Analogously, the arrows of motion point towards smaller $k_{t}$ above the $\Delta k_{t}=0$-curve. From the arrows of motion shown for the complete phase diagram in Figure 2 we conclude that the equilibrium at the intersection of both curves is globally saddlepoint-stable. The unique solution that fulfils the first order conditions (and the corresponding transversality condition) for the households' consumption maximization problem, i.e. the policy function $c_{t}\left(k_{t}\right)$, is given by a (discrete) movement along the stable manifold towards the equilibrium. 


\section{References}

Auerbach, A.C., 2002, Taxation and corporate financial policy in: A.C. Auerbach and M. Feldstein, eds. Handbook of Public Economics Vol. 3, North Holland, Amsterdam, 1251-1292.

Ballard, C.L., D. Fullerton, J.B. Shoven, and J. Whalley, 1985, A General Equilibrium Model for Tax Policy Evaluation, National Bureau of Economic Research, Chicago.

Bernanke, B. and M. Gertler, 1989, Agency costs, net worth and business fluctuations, American Economic Review, 79, 14-31.

Bernanke, B. and M. Gertler, 1996, Inside the black box: The credit channel of monetary policy transmission, Journal of Economic Perspectives 9, 27-48.

Bernanke, B., M. Gertler, and S. Gilchrist, 1999, The financial accelerator in a quantitative busines cycle framework, in: Taylor, J.B. and M. Woodford (ed.), Handbook of Macroeconomics Vol. 1C, NorthHolland, Amsterdam.

Brunner, M. and H. Strulik, 2002, Solution of perfect foresight saddlepoint problems: a simple method and applications, Journal of Economic Dynamics and Control 26, 737-753.

Brunner, M. and H. Strulik, 2004, A simple and intuitive method to solve small rational expectations models, Journal of Economics 82, 71-88.

Carey, D., and H. Tchilinguirian, 2000, Average effective tax rates on capital, labour, and consumption, OECD Working Paper No. 258

Carlstrom, C.T. and T.S. Fuerst, 1997, Agency costs, net worth and business fluctuations: a computable general equilibrium analysis, American Economic Review, 87, 893-910.

Carlstrom, C.T. and T.S. Fuerst, 2001, Monetary shocks, agency costs, and business cycles, Carnegie Rochester Conference Series on Public Policy 54, 1-27.

Chirinko, R.S., Fazzari, S.M., and A.P. Meyer, 1999; How responsive is business capital formation to its user costs? An exploration with micro data, Journal of Public Economics 74, 53-80.

Cummins, J.G., K.A. Hassett, and R.G. Hubbard, 1996, Tax reforms and investment: a cross-country comparison, Journal of Public Economics 62, 237- 273.

J. Diaz-Gimenez, E.C. Prescott, T. Fitzgerald, and F. Alvarez. 1992, Banking in general equilibrium, Journal of Economic Dynamics and Control 16, 533-559.

Fazzari, S.M., R.G. Hubbard, and B.C. Petersen, 1988, Financing constraints and corporate investment, Brookings Papers on Economic Activity 1, 141-195.

Fuerst, T.S., 1995, Monetary and financial interactions in the business cycle, Journal of Money, Credit, and Banking 27(4), 1321-1338.

Gertler, M. and R.G. Hubbard, 1993, Corporate financial policy, taxation, and macroeconomic risk, Rand Journal of Economics 24(2), 286-303.

Gilchrist, S. and C. Himmelberg, 1998, Investment, fundamentals and finance, NBER Working Paper No. 6652.

Gordon, R.H and Y. Lee, 2001, Do taxes affect corporate debt policy? Evidence form U.S. corporate tax return data, Journal of Public Economics 82, 195-224. 
Graham, J.R., 1999, Do personal taxes affect corporate financing decisions?, Journal of Public Economics $73,147-185$.

Graham, J.R., 2000, How big are the tax benefits of debt?, Journal of Finance 55(5), 1901-1941.

Hubbard, R.G.,1998, Capital market imperfections and investment, Journal of Economic Literature 36(1) 193-225.

Kimball, M.S. and M.D. Shapiro, 2003, Labor supply: are income and substitution effects both large or both small?, University of Michigan Working Paper.

Lee, Y. and R.H. Gordon, 2005, Tax structure and economic growth, Journal of Public Economics 89, 1027-1043.

Lucas, R.E., Jr., 1990, Supply-Side Economics, An Analytical Review, Oxford Economic Papers 42, 293-316.

Mendoza, E.G., G.M. Milesi-Ferretti, and P. Asea, 1997, On the ineffectiveness of tax policy in altering long-run growth: Harbergers's superneutrality conjecture, Journal of Public Economics 66, 99-126.

OECD, 1991, Taxing Profits in a Global Economy: Domestic and International Issues, OECD, Paris.

Osterberg, W.P., 1989, Tobin's $q$, investment, and the endogenous adjustment of financial structure, Journal of Public Economics 40, 293-318.

Sinn, H.W., 1987, Capital Income Taxation and Resource Allocation, Amsterdam, North-Holland.

Strulik, H., 2003, Capital tax reform, corporate finance, and economic Growth and welfare, Journal of Economic Dynamics and Control 28, 595-615.

Townsend, R.M., 1979, Optimal contracts and competitive markets with costly state verification, Journal of Economic Theory.

Turnovsky, S.J., 1982, The incidence of taxes:a dynamic macroeconomic analysis, Journal of Public Economics 18, 161-194.

Turnovsky, S.J., 1990, The effects of taxes and dividend policy on capital accumulation and macroeconomic behavior, Journal of Economic Dynamics and Control 14, 491-521. 